\title{
Dealing with Project Characteristics through Concurrent Product Development by Malaysian Car Producer
}

\author{
H. Boejang1, H. Ariff², M. Z. Hassan³ ${ }^{3}$, S. Esa \\ ${ }^{1 \cdot 3}$ Fakulti Teknologi Kejuruteraan Mekanikal dan Pembuatan, Universiti Teknikal Malaysia Melaka, Malaysia \\ Hang Tuah Jaya, 76100 Durian Tunggal,Melaka, Malaysia. hambaliboejang @utem.edu.my \\ ${ }^{2}$ Faculty Kejuruteraan Pembuatan, Universiti Teknikal Malaysia Melaka, Malaysia \\ Hang Tuah Jaya, 76100 Durian Tunggal, Melaka, Malaysia. hambali@utem.edu.my \\ $\neg$ Perusahaan Otomobil Nasional Sdn Bhd, Persiaran Kuala Selangor, Seksyen 26, 40400 Shah Alam, Selangor \\ Darul Ehsan, Malaysia. saharue@proton.com
}

\begin{abstract}
This research work explores and identifies the new product development (NPD) project complexity and its sources of a small-sized (low volume) car manufacturer in Malaysia. It explains the approach used by this producer to overcome the project characteristics as well. In order to understand the research topic, related literatures were reviewed and information was gathered to develop questionnaire. Later, the questionnaire was pre-tested prior to the interview sessions with relevant respondents from various functions. The feedback was used to identify and specify the source of project complexity, the types of product development projects, and the approaches adopted by the producers to vanquish project complexity. The results show that the producer defines the type of development projects and the level of project complexity according to the change contents of the vehicle and the powertrain. The car producer mitigates and eliminates project complexity and uncertainty through the adoption of concurrent engineering practices, robust planning, and co-development. However, the product radical innovation is not the factor that really affects the project complexity in the new product development effort for this Malaysian small-sized car producer.
\end{abstract}

Key words: New Product Development; Project Complexity; Product-Process Complexity; Uncertainty and Innovation; and Project characteristics

\section{INTRODUCTION}

This research is underpinned by the suggestion that the choice of a NPD practice should be determined by the project characteristics [1]. It has been discussed in many literatures that big producers of top brand vehicles over the world have taken the new product development as a strategic business approach to remain competitive $[2,3]$. They have adopted certain development processes that are appropriately meeting the demand from the emerging technologies and market globalization. To have a decent frequency of the new product introduction (NPI), the car producer adopts the integrated product development approach through concurrent engineering (CE). In order to achieve certain projects goals, a car producer must overcome the project complexity and uncertainty that affect the product development project performance. Of late, many research works on NPD have made product development project characteristics as an interesting topic to be explored and studied. These previous research projects discuss the factors that determine the level of project complexity, and the relationship between these factors with project outcomes such as productivity, design quality, unit-cost and development time [4-6]. Some researchers studied about the enablers for $\mathrm{CE}$ such in the research work that presented by Cusumano and Nobeoka [7] with regard to project complexity. The success or failure factors of product development performance are obvious and have been explicitly discussed and identified in many literatures as well [8-11]. To improve the understanding of a firm-level NPD project performance of a small-sized car producer, this research work explores this particular matter in a late industrialization nation: Malaysia as the information about its NPD process and project is scant.

A well-organized NPD is normally represented by phases, gateways and milestones with dedicated development timings. It starts with planning phase and ends-up with product launching and continues with mass-production [12]. Different development phase is assigned with different gateways and milestones, and of course with different specific evaluation criteria and expected deliverables. The gateway is a crucial event where the major meeting is held to deliberate and decide on the directions of the development process. A specific NPD process is adopted by a manufacturer for several reasons or conditions which are critical, and significantly able to improve the efficiency and effectiveness of the NPD performance. Unger and Eppinger [13] see the NPD process as how an organization managing risks and uncertainties, whereas Kahn et al. [14] interpret the approach as a tool to solve deficiencies in NPD. These scholars highlighted the importance of top management involvement and 
cross-functional development team in the NPD process to overcome challenges from project characteristics and to sustain project goals. The development project is classified into several categories i.e. the new platform, modified, and enhancement based on certain criteria and purposes. For example, Mahmoud and Lenfle [9] who specify that the platform re-use in product development efforts enables firm to come up with new product variant and at the same time satisfy customer needs. Meanwhile, Wheelwright and Clark [10] classify the types of the development projects into breakthrough, platform, derivative and R\&D projects. Both of them classified development project according to degree of change in the product and also in the manufacturing process with different degree of product-process complexity and risks.

The product development project complexity has two influencing factors which come from changes in the market and technology that demand optimum product development performance, individually as well as overall $[4,11]$. Yet, the definition of project complexity in NPD has not been agreed upon among researchers; still project complexity is an interesting topic for many over the past years. Lebcir [15] comes up with a framework of project complexity and discussed in detail about product complexity and innovation. He found that the source of product complexity comes from the product size, and product architecture. Meanwhile, the challenges from innovation are driven by the product newness and the project uncertainty. Moreover, according to Elmaraghy et al. [16] the project complexity can be seen from three perspectives: the complexity of the engineering design and the product development process, the complexity of the manufacturing process, and finally the complexity of the global supply-chain and managing the entire business. Similarly, Hussein, et al. [17] find that there are three major sources that contribute to complexity: the technology independence, the technology novelty, and the external factor.

Many scholars have also studied the effect of supplier involvement in the new product development efforts and its impact on the product development performance [18, 19]. The business strategy of having earlier involvement of the supplier benefits the firm in terms of cost, lead-time and quality [20] and allows the producer to reduce or avoid the intensity of project complexity and uncertainty and encouraging innovation [21, 22]. According to Chaudhuri and Boer [23] the co-development strategy in NPD is one way of dealing with product-process complexity. As such, in order to improve the understanding of a firm-level NPD project performance, this research work explores this particular matter in the context of the automotive world, but in a late industrialization nation: Malaysia, as the information about this particular car producer and its NPD process and project is scant

\section{METHODOLOGY}

This study adopts the qualitative research design approach in order to answer the research questions. The research questions are:

a. What are the factors that contribute to product development project complexity?

b. How this small-sized car producer overcomes its product development project complexity?

Information was gathered via systematic research review method by which documents were reviewed across several databases such as SCOPUS, Google Scholar, and IEEE Explore. The documents were first extracted based on years of publication from 1990 to 2017. Second, they must be available in full text in English. Third, the publications had to include all the peer-reviewed articles and relevant to new product development. Forth, the publication must consider reliable writers who have had more than 5 publications related to the topic and must have more than five citation after 2000. And finally, the publications were categorized into specific folders in Mendeley software, and duplicate publications were deleted as depicted in Figure 1.

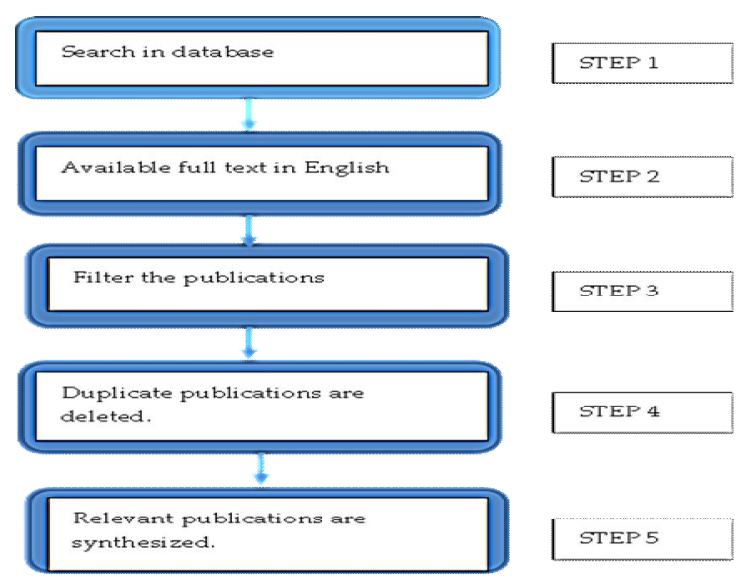

Figure 1: The selection process of the literature review.

From the literatures, the questionnaire was designed and developed. Draft version of the questionnaire was sent off via email to the contact person for pre-testing purpose. Once the feedback was obtained and the questionnaire was fined tuned, a face-to-face open-ended semi-structured interview was planned and scheduled. The participations include a senior manager from the planning division and a senior executive from the NPI unit, together with two project managers from two different vehicle programs, and four development team members. The interview covers without limitation the formal NPD process, the product-process complexity, and the countermeasures. 


\section{RESULTS AND DISCUSSSION}

It is found that for this small-sized car producer, the most important product development project goals are low development cost, and shorter development lead-time. In addition, the data shows that there are several approaches applied by the producer to manage product-process complexity, uncertainty, and incremental innovation. In short, the producer adopts and applies solutions that can be seen from three points of views: the development project strategy, the CE best practices and the co-development as shown in Table 1

Table 1: The solutions for the NPD project characteristics.

\begin{tabular}{|l|l|}
\hline View & $\begin{array}{l}\text { Solution for Project } \\
\text { Characteristics }\end{array}$ \\
\hline $\begin{array}{l}\text { The development } \\
\text { project scope } \\
\text { (project strategy) }\end{array}$ & $\begin{array}{l}\text { Guideline for product change } \\
\text { content and powertrain change } \\
\text { content. }\end{array}$ \\
\hline $\begin{array}{l}\text { The concurrent } \\
\text { product } \\
\text { development best } \\
\text { practices. }\end{array}$ & $\begin{array}{l}\text { Concurrent } \\
\text { practices: } \\
\text { i. Top-management } \\
\text { involvement. } \\
\text { ii. Integrated development team. }\end{array}$ \\
\hline & $\begin{array}{l}\text { Phase 0: Market and product } \\
\text { feasibility, technology and } \\
\text { concept. } \\
\text { i. Mule car program } \\
\text { ii. Model-fixed. }\end{array}$ \\
\hline $\begin{array}{l}\text { Phase 1: Product, Process } \\
\text { development, technology and } \\
\text { concept. } \\
\text { i. F-prototype (testing for design } \\
\text { validation). }\end{array}$ \\
\hline $\begin{array}{l}\text { Phase 2: Process validation and } \\
\text { product confirmation } \\
\text { i.P-Prototype (testing for process } \\
\text { validation). }\end{array}$ \\
\hline Supplier involvement \\
\hline Engineering consultant. \\
\hline Co-development
\end{tabular}

\subsection{The Product Development Project Scope}

A formal guideline for a development project is said to be one of the methods used by this car producer in predicting the product-process complexity, uncertainty, and innovation. Table 2 and Table 3 show the car producer defines its product development project scope based on project size which reflects the vehicle change content and the powertrain change content. The combination of these change contents tell about the level of the product-process complexity, the incremental innovation involved as well as the expected development timing. It gives some ideas to the development team about the solution to be used to counter the project characteristics. A complex development project, for example, the new vehicle platform (VC5) that combines with the new engine development (PTC5) requires more attentions and maximum numbers of gateways for monitoring and controlling purposes as well as longer engineering lead-time. The types of development projects are divided into 5 main categories with respect to both change contents.

Table 2: The vehicle changes content (VC).

\begin{tabular}{|l|l|l|}
\hline $\begin{array}{l}\text { Type of } \\
\text { Project }\end{array}$ & Change content & Definition \\
\hline $\begin{array}{l}\text { Enhancement } \\
\text { (VC1) }\end{array}$ & $\begin{array}{l}\text { Color change for } \\
\text { interior and } \\
\text { exterior. } \\
\text { Fabric change } \\
\text { Body kits } \\
\text { Alloy wheel }\end{array}$ & $\begin{array}{l}\text { Minor change of the } \\
\text { image of the } \\
\text { vehicle. }\end{array}$ \\
\hline $\begin{array}{l}\text { Cosmetic } \\
\text { change (VC2) }\end{array}$ & Facelift & $\begin{array}{l}\text { Change that affect } \\
\text { minor styling image } \\
\text { of the vehicle. }\end{array}$ \\
\hline $\begin{array}{l}\text { Skin change } \\
\text { (VC3) }\end{array}$ & $\begin{array}{l}\text { Major change of } \\
\text { body styling }\end{array}$ & $\begin{array}{l}\text { Change that affect } \\
\text { the upper body } \\
\text { styling with carry } \\
\text { over platform. }\end{array}$ \\
\hline $\begin{array}{l}\text { Full model } \\
\text { change (VC4) }\end{array}$ & $\begin{array}{l}\text { Major change of } \\
\text { body styling with } \\
\text { modified } \\
\text { platform }\end{array}$ & $\begin{array}{l}\text { Change that } \\
\text { involves } \\
\text { modification of the } \\
\text { carryover platform } \\
\text { with new } \\
\text { engineering } \\
\text { specifications. }\end{array}$ \\
\hline $\begin{array}{l}\text { New platform } \\
\text { (VC5) }\end{array}$ & $\begin{array}{l}\text { New design } \\
\text { content and } \\
\text { platform }\end{array}$ & $\begin{array}{l}\text { New platform with } \\
\text { complete body style } \\
\text { and platform. }\end{array}$ \\
\hline
\end{tabular}

Table 3: Powertrain change content (PTC).

\begin{tabular}{|l|l|}
\hline Change & Definition \\
\hline PTC0 & $\begin{array}{l}\text { Carryover existing engine and } \\
\text { transmission. }\end{array}$ \\
\hline PTC1 & $\begin{array}{l}\text { Carryover existing engine and } \\
\text { transmission with minor } \\
\text { recalibration. }\end{array}$ \\
\hline PTC2 & $\begin{array}{l}\text { Minor engine and transmission } \\
\text { modification and major recalibration }\end{array}$ \\
\hline PTC3 & $\begin{array}{l}\text { Existing engine and transmission } \\
\text { with new calibration and major } \\
\text { modification. }\end{array}$ \\
\hline PTC4 & $\begin{array}{l}\text { Major upgrade of the engine and } \\
\text { transmission performance. }\end{array}$ \\
\hline PTC5 & $\begin{array}{l}\text { New engine and transmission } \\
\text { development. }\end{array}$ \\
\hline
\end{tabular}


The change contents give clues to the development team in predicting the upcoming project complexity and uncertainty as well as the innovation. It allows the development team to strategize and plan its NPD and be very up-front about all the related requirements. It also gives the development team enough time in shortlisting capable and relevant supplier for sub-contracting certain development tasks to the suppliers and engineering consultant. This guideline enables the development team to prepare relevant countermeasures for product-process complexity as well as uncertainty. The respondents also emphasized that most of the development projects use market available technological components or systems for its products. This is due to the limitation on the R\&D capability, and also owing to the monetary and expertise constraints. The car producer does not profoundly involve in product radical innovation, as the producer simply buys any new related technology available or ask its vendor or subsidiary to out-source the required technology. However, it will definitely have to counter the challenges from the incremental innovation of the vehicle and powertrain change contents.

\subsection{The Concurrent Product Development and Co-Development}

The product development process was initially adopted from its partner - a Japan car producer. However, in the early year of 2000, this car producer had managed to develop its own formal NPD known as the new product introduction as shown in Figure 2.

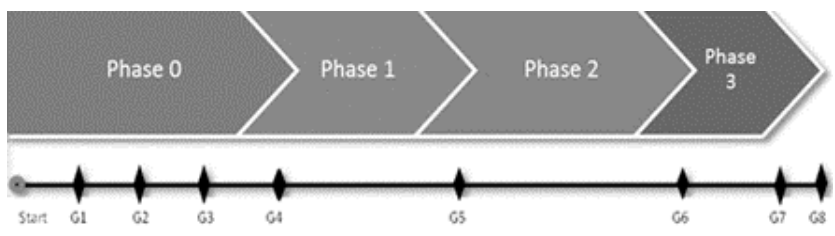

Figure 2: The New Product Introduction of the Malaysian Car Producer [12].

Figure 2 shows the NPD is represented by four development phases and eight gateways (G1 - G8). The number of gateways is higher within phase 0 due to higher level of the product-process complexity and uncertainty. Handling this initial stage known as the fuzzy front-end is an important and difficult task in the NPD [24]. According to the respondents this is the crucial stage in the development process as the product to be introduced is measured against specific evaluation criteria that are pre-determined before the project commences. This includes ambiguity criteria that are differed at each phase. The highest level of important progress meetings is held at all gateways and chaired by top management personnel. Other participants who involve in the gateway's meeting are the project director, general manager, project manager and related department heads. The top management involvement has become one way of managing the project complexity and uncertainty. For instance, at phase
0 , it requires intense involvement of the top management because of the higher level of risks and uncertainties that demand for astute decisions. The top management's decisions include the resource allocation and commitment with regard to budget allocation and manning level, and authority. The cross-functional development team has become one of the mechanisms for the producer to manage and control the project complexity and uncertainty. The development team usually consists of senior engineers from different functions.

The development team members are recommended by the functional managers from different departments. Only the project manager is selected by the top management. The development team has become the central unit in processing information required for the development activities. The main responsibility for the development team is coordinating and facilitating the development tasks. The team will process the information and do follow-up through meetings to check the status of the development progress i.e. the deliverables and milestones. The development team will also communicate and coordinate development tasks with the functional team, supplier and engineering consultant who have been assigned or awarded with contract on certain development tasks accordingly. This type of team structure is so far best fit with the car producer owing to some constraints such as the limited number of the man-powers and NPD's expertise and other pool of resources.

In addition, the car producer has used its formal NPD routines to manage the development issues pertaining to the project complexity and uncertainty. The planning phase (phase 0 ) is where the developed product undergoes two main development routines: the mule car program and the model fixed. Many scholars have emphasized the importance of an early planning in NPD, and associated it with project complexity [5, 25]. The mule car program is where a similar product from the competitor is benchmark for comparative analysis in getting better understanding on the applicable technology and design. Meanwhile, the model-fixed is where the concept design of the developed product is frozen to allow final decision to be made on the interior and exterior styling. It is a crucial stage where decisions on uncertainty pertaining to concept of the interior design are made whether it should be proceeded, abandoned or put on hold [26].

There are two types of prototype tests during NPD process: The F-prototype is used to validate the design of the product and it takes place during phase 1. Prototypes are built using technology such as additive manufacturing and rapid tooling used for various engineering purposes i.e. form, fit and visualization purposes [27]. In contrast, P-prototype is used to validate the manufacturing process for the developed product. This is done during phase 2 where the P-prototypes are fabricated using soft tooling with similar process and materials used in an actual production. 
Many scholars have insisted that the early supplier involvement helps firm to overcome project characteristics $[18,28]$. From the data, there are two main external groups involve in a complex development project: the suppliers that design, manufacture and supply the component and/or sub-assembly, and the engineering consultants that provide services for engineering design or process engineering. The supplier who involves with new product development project is the first-tier vendor. For the engineering consultant, the involvement only takes place during the NPD process. There are two types of engineering consultants used by this car producer: the design house and the process engineering company. Both involve during phase 0 , and design-manufacturing interface respectively. According to the respondents, the co-development helps them to catch up with the development time, even though it may increase the development cost. The trade-off is acceptable as the supplier and the engineering consultant have to deliver the contract and solve the product-process complexity and uncertainty and share the knowledge with the development team.

\section{CONCLUSION}

It can be concluded that for this small-sized car producer:

- The formal NPD process itself is important and has been used to manage project characteristics.

- The product development project complexity is defined according to the project size (the vehicle change content and the powertrain change content) which reflect the types of the product development project and the timings. For complex development projects, the level of risks and uncertainties is high and intense.

- The involvement of top management and integrated development team, and co-development has helped the car producer to overcome and/or reduce project characteristics.

- Product planning together with prototype testing at different phases of NPD is crucial and allows the producer to mitigate the negative effects of project characteristics, thus; accelerates the development process.

\section{ACKNOWLEDGEMENTS}

This research was conducted with the support from Perusahaan Otomobil Nasional Sdn. Bhd. (PROTON), and sponsored by Universiti Teknikal Malaysia, Melaka (UTeM).

\section{REFERENCES}

1. S. Ahmad, D. N. Mallick and R. G. Schroeder, "New product development: Impact of project characteristics and development practices on performance", Journal of Product Innovation
Management, vol. 30, no. 2, pp. 331-348, 2013. https://doi.org/10.1111/j.1540-5885.2012.01002.x

2. K. T. Ulrich and S. D. Eppinger, Product Design and Development. 5th Edition. New York: McGraw Hill, 2012.

3. M. Graner and M. Mißler $\square$ Behr, "Key determinants of the successful adoption of new product development methods", European Journal of Innovation Management, vol. 16, no. 3, pp.301-316, 2013.

4. M. V. Tatikonda and S. R. Rosenthal, "Technology novelty, project complexity, and product development project execution success: A deeper look at task uncertainty in product innovation", IEEE Transactions on Engineering Management, vol. 47, no. 1, pp. 74-87, 2000 .

5. C. Stockstrom and C. Herstatt, "Planning and uncertainty in new product development", $R \& D$ Management, vol. 38, no. 5, pp. 480-490, 2008. https://doi.org/10.1111/j.1467-9310.2008.00532.x

6. H. Sicotte and M. Bourgault, "Dimensions of uncertainty and their moderating effect on new product development project performance", $R \& D$ Management, vol. 38, no. 5, pp. 468-479, 2008.

7. M. A. Cusumano and K. Nobeoka, "Strategy, structure and performance in product development: Observations from the auto industry", Research Policy, vol. 21, no. 3, pp. 265-293, 1992.

8. R. G. Cooper and E. J. Kleinschmidt, "Benchmarking the firm's critical success factors in new product development", Journal of Product Innovation Management, vol. 12, no. 5, pp. 374-391, 1995. https://doi.org/10.1111/1540-5885.1250374

9. S. Ben Mahmoud $\square$ Jouini and S. Lenfle, "Platform re $\square$ use lessons from the automotive industry", International Journal of Operation and Production Management, vol. 30, no. 1, pp. 98-124, 2010.

10.S. C. Wheelwright and K. B. Clark, "Creating project plans to focus product development", Harvard Business Review, vol. 70, no.2, pp. 70-82, 1992.

11.L. Bstieler, "The Moderating Effect of Environmental Uncertainty on New Product Development and Time Efficiency", Journal of Product Innovation Management, vol. 22, no. 3, pp. 267-284, 2005. https://doi.org/10.1111/j.0737-6782.2005.00122.x

12.H. Boejang, H. Ariff, M.Z. Hassan, S. Esa and M. Rauterberg, "An exploration on new product development process of Malaysian small-sized automaker", Journal of Advanced Manufacturing Technology", vol. 11, no. 2, pp.33 - 46, 2017.

13.D. W. Unger and S. D. Eppinger, "Comparing Product Development Processes and Managing Risk", International Journal Product Development, vol. 8, no. 4, pp. 382-402, 2009.

14. K. B. Kahn, S. E. Kay, R. J. Slotegraaf and S. Uban, The PDMA Handbook of New Product Development, 3rd Edition. New Jersey: John Wiley and Sons Inc., 2013. 
H. Boejang et al., International Journal of Emerging Trends in Engineering Research, 7(12), December 2019, $784-789$

15. M. Lebcir, "A Framework for Project Complexity in New Product Development (NPD) Projects", Business School Working Papers. Vol. UHBS 2006-1, University of Herrtfordshire, 2006.

16. W. Elmaraghy, H. Elmaraghy, T. Tomiyama and L. Monostori, "Complexity in engineering design and manufacturing", CIRP Annals - Manufacturig Technology, vol. 61, no. 2, pp. 793-814, 2012.

17. B. A. Hussein, G. Pigagaite and P. P. Silva, "Identifying and Dealing with Complexties in New Product and Process Development Projects", Procedia - Social and Behavioral Sciences, vol. 119, pp. 702-710, 2014. https://doi.org/10.1016/j.sbspro.2014.03.078

18. F. Caniato and A. Größler, "The moderating effect of product complexity on new product development and supply chain management integration", Production Planning Control, vol. 7287, no. 6, pp. 1-12, 2015.

19. P. Danese, "Supplier integration and company performance: A configurational view", Omega, vol. 41, no. 6, pp. 1029-1041, 2013.

20]. G. L. Ragatz, R. B. Handfield and K. J. Petersen, "Benefits associated with supplier integration into new product development under conditions of technology uncertainty", Journal of Business Research, vol. 55, no. 5, pp. 389-400, 2002.

21. X. Koufteros, M. Vonderembse and J. Jayaram, "Internal and external integration for product development: The contingency effects of uncertainty, equivocality, and platform strategy", Decision Sciences, vol. 36, no. 1, pp. 97-133, 2005.

22. L. Melander and F. Tell, "Uncertainty in collaborative NPD: Effects on the selection of technology and supplier", Journal of Engineering Technology Management-J-Met, vol. 31, no. 1, pp. 103-119, 2014.

23. A. Chaudhuri and H. Boer, "The impact of product-process complexity and new product development order winners on new product development performance: The mediating role of collaborative competence", Journal of Engineering Technology Management - JET-M, vol. 42, pp. 65-80, 2016.

24. J. Kim and D. Wilemon, "Focusing the fuzzy front-end in new product development", $R \& D$ Management, vol. 32, no. 4, pp. 269-279, 2002.

https://doi.org/10.1111/1467-9310.00259

25. J. Derbyshire and E. Giovannetti, "Understanding the failure to understand New Product Development failures: Mitigating the uncertainty associated with innovating new products by combining scenario planning and forecasting", Technological Forecasting Social Change, vol. 125, pp. 334-344, 2017.

26. P. Spieth and V. Joachim, "Reducing front end uncertainties: How organisational characteristics influence the intensity of front end analysis", Technological Forecasting Social Change, vol. 123, pp. 108-119, 2017.
27. H, Boejang, M.F. Basar, Time Compression Technologies for Engineering Technology, 1st Edition. Penerbit Universiti Teknikal Malaysia Melaka, 2013.

28. A. Cabigiosu, F. Zirpoli and A. Camuffo, "Modularity, interfaces definition and the integration of external sources of innovation in the automotive industry", Research Policy, vol. 42, no. 3, pp. 662-675, 2013. https://doi.org/10.1016/j.respol.2012.09.002 